\title{
Практика реализации права на гражданство в странах Прибалтики
}

Чернолеикий В.Б.

Правовое положение личности в современном государстве представляет собой основной элемент государственного строя, поскольку именно в этой правовой форме происходит общение государства как целого с личностью, конкретным человеком. Конструкция правовой формы гражданства в науке ${ }^{1}$ рассматривается в качестве правовой связи: комплекса взаимных прав и обязанностей. Внутреннее законодательство в принципе следует за этим определением. Так, например, поступает латвийский закон о гражданстве, устанавливающий в своем первом разделе, что гражданство Латвии - это «постоянная правовая связь лица с Латвийским государством». Но первая проблема, которая дает о себе знать в этой связи, это вопрос, насколько наличие у человека права на гражданство предопределяет реальную возможность обладания этим правом. Именно этот вопрос становится чрезвычайно актуальным в свете практики прибалтийских «держав» в области законодательства о гражданстве.

Как известно, реальная возможность получения такого права или его реализации относится современным международным правом к основным, фундаментальным правам личности, что при провозглашаемом примате международного права над внутренним становится своеобразной conditio sine qua non цивилизованности государственного строя того или иного государства. Формально конституции прибалтийских государств содержат такие положения, например ст. 3 эстонской конституции, но как обстоит дело на практике - вот в чем вопрос.

Один из способов решения этого вопроса предлагает международное право. Международное право в качестве непреложной нормы предполагает осуществление оптации ex lege при изменении территории государства. Так, ст. 10 Конвенции ООН о сокращении лиц без

\footnotetext{
* Чернолецкий Владимир Борисович - заместитель начальника отдела научного планирования Управления научной политики МГИМО.

1 Международное право, например, в известном прецеденте Международного суда: Nottebohm case, 1955, определяет институт гражданства как: «...правовую связь, свидетельствующую о социальном факте принадлежности, подлинной связи с существом, интересами и чувствованиями, а равно с имеющимися в наличии правами и обязанностями». Цит. по: Consequences of state succession for nationality. Report by the Venice commission. Strasbourgh, 1998. P. 15.
} 
гражданства 1961 г. гласит: «...любое договаривающееся государство, которому передается территория, должно предоставлять свое гражданство тем лицам, которые иначе стали бы апатридами в результате такой передачи или такого приобретения». Конечно, не все прибалтийские страны подписали эту конвенцию, как, например, Эстония, или ратифицировали ее, как Латвия. Но сама конвенция содержит императивную норму ius cogens, игнорировать которую государства не вправе. Но балтийская логика дает о себе знать и здесь 2 .

Избирательность в применении норм международного права прибалтийскими режимами пока еще получает поддержку со стороны Западного сообщества. Здесь пока еще можно встретить оправдание подобной циничной позиции прибалтов тем, что эти народы «пострадали» за свою пятидесятилетнюю историю и им необходим срок для восстановления. Хочется при этом только спросить: чего именно? Психики или уважительного отношения к общепризнанным символам цивилизованности, одним из которых является современное международное право? Поэтому способна вызвать только удивление позиция международных организаций в области прав человека, наивно утверждающих, что «специальные процедуры получения гражданства должны будут найти применение» ${ }^{3}$ в этих странах. Истины ради стоит признать, что под нажимом Запада прибалтам все же пришлось пойти на ряд уступок, не уступив, тем не менее, в главном - в реституционном подходе к решению вопроса о гражданстве.

«Поскольку международная правосубъектность прибалтийских стран, - начинает вещать одна бойкая латышская юристесса, - не погашена и поэтому они продолжают существовать, по крайней мере de iure, как государства в международном праве, то поэтому вероятно предположить, что гражданство и права человека, их состояние в прибалтийских странах не могут быть рассмотрены вне дискуссии о международно-правовом статусе этих государств» ${ }^{4}$. Логика тут следую-

2 Особенности стиля правового мышления прибалтов проанализированы нами в другой статье: Чернолецкий В.Б. О так называемой идентичности нынешних государств Прибалтики // Московский журнал международного права. 2007. № 1.

3 Consequences of state succession for nationality. Р. 38. Так и хочется спросить автора этого доклада, а он понимает, что прибалтийский менталитет не видит причинноследственной связи между конструкциями «должен получить» и «действительно получили»?

${ }^{4}$ Ziemele I. The role of state continuity and human rights in matters of nationality of the Baltic states. // The Baltic states at historical crossroads. Riga, 1998. P. 249-250. 
щая. Поскольку ст. 1 еще Гаагской конвенции 1930 г. «О конфликте национальных законов в области гражданства» допускает приоритет внутреннего права над международным в вопросах определения гражданства и поскольку международное право не позволяет оккупационной власти вмешиваться в вопросы гражданства оккупированной территории, то действия прибалтийских государств в этой сфере должны выглядеть вполне благопристойно. Советский Союз не имел права предоставлять свое гражданство гражданам довоенных прибалтийских лимитрофов, а раз акты советской власти недействительны, действенны акты, законы о гражданстве названных стран. Поэтому, «восстановив» свой континуитет в 1991 г., эти государства восстановили свое гражданство и не были обязаны предоставлять его всем, кто проживал на момент восстановления континуитета на их территории ${ }^{5}$.

Утверждение, конечно, во многом риторическое. Гражданство, дескать, как и государство, имеет свой континуитет. Раз так, то как быть с банальными актами регистрации гражданского состояния, произведенными в годы «советской оккупации»? А как быть с оформлением брачных отношений? Прибалты выезжали за пределы Советского Союза по недействительным советским загранпаспортам? Но почему-то ни одна страна, куда прибалты выезжали по этим паспортам, не рассматривала их как недействительные. Как быть с образованием, регалиями, чинами и прочим, полученными от советской власти услужливыми потомками лакеев немецких баронов?

Логика, повторим, убийственная. Она способна сыграть весьма злую шутку со своими апологетами. Основа рассуждений следующая: прибалтийские страны идентичны предвоенным, потому что США и ряд стран Запада не признали аннексию СССР законной, следовательно, континуитет гражданства предвоенных государств распространяется в основном на потомков тех граждан, что проживали здесь до оккупации. Отлично, скажем мы, но вот Россия не признает факт аннексии и оккупации Советским Союзом названных стран, следовательно, нет никакой идентичности и континуитета. Вот и вся логика: кто-то признает, а кто-то не признает. Как субъекты международного права США и Россия равны, следовательно, с точки зрения права никакой разницы в доказательности их позиции нет.

Представляется, что в основе логической ошибки, которая опосредует позицию прибалтов, находится известное противоречие,

5 Ibidem. P. 256. 
определенное в диалектике как закон перехода количества в качество, который представляет собой terra incognito для сознания прибалтийских «европейцев». Тем не менее закон этот, применимый к ситуации с признанием и непризнанием какого-то факта субъектами международного права, гласит только одно. Субъект, как правовая сущность, равен не просто другому субъекту (вне зависимости от размера его территории, экономической или военной мощи), а совокупности всех остальных субъектов вместе взятых. Если, допустим, А знает, что $2 \times 2=4$, то А равен в своем знании миллиону других А или Б, чье знание идентично. На этот простой в общем-то логической основе и держится современная система международных отношений, ведущая начало от укоренения принципа суверенного равенства государств после Вестфальского мира. Если прибалтам вслед за их заокеанскими покровителями хочется отменить эту систему, то это проблема их хотения, но никак не международного сообщества.

\section{$* * *$}

Тем не менее вектор развития законодательства в области гражданства прибалтийскими странами был избран строго реституционный. Исключение, повторим, было сделано властями Литвы. Но не в самом главном; здесь, как и в Эстонии и Латвии, основа законодательства по этому вопросу была взята из прошлого - образцом послужил закон о гражданстве Литовской Республики 1938 г. На его основе 3 ноября 1989 г. был принят Закон Литовской ССР о гражданстве, замененный в 1991 г. новым законом. Ныне в Литве действует закон о гражданстве от 17 сентября 2002 г.

В Эстонии основа законодательства по этому вопросу оказалась более стабильной. При «восстановлении» государственности власти установили фикцию продолжения действия закона о гражданстве Эстонской республики 1938 г. с дополнениями 1940 г. Ныне действует закон от 19 января 1995 г. с последующими изменениями. В Латвии постарались придерживаться такой же позиции: восстановленный в 1991 г. закон о гражданстве 1919 г. с поправками 1927 г. был заменен в 1998 г. ныне действующим актом.

В прибалтийских странах конституционные акты устанавливают основу института гражданства, прав и свобод. В этом лимитрофы следуют общей практике. Так, в конституции Латвии 1998 г. этим вопросам посвящена отдельная глава - восьмая, в которой, однако, 
мы не найдем конкретного фиксирования статуса гражданина. Латвийская конституция знает этот термин в качестве абстрактного понятия, своего рода в качестве единицы латвийского народа. Положение это объяснимо довольно долгим процессом формирования компромисса по общему вопросу прав человека в этой стране 6 . Почти восемь лет латвийское общество провело в долгих спорах на эту тему.

Совсем иное положение в Литве. Здесь конституция 1992 г. в ст. 12 и 13 устанавливает основы собственного гражданства, отдавая приоритет ius sanguis, особо оговаривается запрет двойного гражданства. Литовское государство торжественно провозглашает защиту своих граждан, где бы они ни находились, запрещая выдачу своего гражданина другому государству иначе как в порядке, предусмотренном международным договором. Аналогичные положения мы встречаем и в Эстонской конституции 1992 г., где ст. 8 отдает приоритет праву крови (ср. п. 3 § закона о гражданстве 1995 г.), одновременно запрещая лишение гражданства за политические убеждения. Статья 3 эстонской конституции объявляет о покровительстве государства в отношении своих граждан, находящихся за рубежом. Конституции прибалтийских государств в качестве общего принципа признают равенство прав и свобод в отношении собственных граждан, иностранцев и апатридов.

\section{$* * *$}

Итак, главный принцип, положенный в основу приобретения гражданства названных стран, - это рождение от родителей - граждан соответствующего государства вне зависимости от места рождения (раздел 2 латвийского закона, § 2 эстонского и ст. 7 литовского). Общим положением считается, что для получения гражданства достаточно, чтобы хотя бы один из родителей был гражданином соответствующего прибалтийского государства. Затем акты признают в качестве источника гражданства натурализацию, условия прохождения которой разнятся в зависимости от страны. Возобновление гражданства - еще один из способов его получения.

Однако особое положение в законодательных актах занимают те нормы, которыми определяется гражданство на момент получения независимости. Хотя точнее было бы сказать, кто имеет право

6 Таково вполне аргументированное мнение К. Таубе: Taube C. Constitutionalism in Estonia, Latvia and Lithuania. A study in comparative law. Uppsala, 2001. P. 123. 
на получение литовского гражданства. Это особенно хорошо видно на примере литовского законодательства.

Так, закон 2002 г. в ст. 1 (его положения во многом предопределены были постановлениями закона 1989 г.) определяет: «Гражданами Литовской Республики являются: 1) лица, состоявшие до 15 июня 1940 г. в гражданстве Литвы, их дети, внуки и правнуки; 2) лица, постоянно проживавшие в период с 9 января 1919 г. по 15 июня 1940 г. на теперешней территории Литовской Республики, а также и дети, внуки и правнуки, если они на день введения в действие закона о гражданстве постоянно проживали и в настоящее время постоянно проживают на территории Литовской Республики и не являются гражданами другого государства; 3 ) лица литовского происхождения, если они не являются гражданами другого государства. Лицом литовского происхождения считается лицо, родители или дедушки и бабушки либо один из родителей или дедушек и бабушек которого являются или были литовцами и которое само признает себя литовцем; 4) лица, приобретшие до 4 ноября 1991 г. гражданство Литовской Республики в соответствии с принятым 3 ноября 1989 г. законом о гражданстве...».

Весьма знаменательный текст - конечно, не своей очевидной нелепостью вроде лиц, которые «являются или были литовцами», - плеоназм сродни выражению «перекрасившийся негр». Важно тем не менее то, что Литва пошла по пути, предписываемому международным правом, и установила положение об оптации как о способе получения гражданства лицами нелитовского происхождения. В законе, на который ссылается ныне действующий акт, значится: «Другие лица, которые на день вступления в силу настоящего закона постоянно проживали на территории республики и имеют здесь постоянное место работы или постоянный легальный источник существования. Эти лица в течение двух лет со дня вступления в силу настоящего закона свободно самоопределяются о гражданстве», п. 3 ст. 1 закона о гражданстве Литовской ССР 3 ноября 1989 г. Но, повторим, - это было не более чем счастливое исключение. В актах Латвии или Эстонии вы ничего подобного не найдете.

Латвийский закон довольно непреклонен, правом на гражданство обладают лица, бывшие гражданами Латвийского государства до 17 июня 1940 г., и их потомки, зарегистрированные в должном порядке, за исключением тех, кто получил гражданство другого государства после 4 мая 1990 г. Затем следуют латыши и ливы, постоянно проживающие в Латвии, не имеющие гражданства другого государства, 
должным образом зарегистрированные. Новелла 1998 г., введенная в закон под давлением международных организаций, дает право на получение гражданства лицам, имеющим среднее образование, полученное на латышском языке, постоянно проживающим в Латвии, должным образом зарегистрированным, не имеющим гражданства другого государства. Дети этих лиц до 15-летнего возраста в равной мере пользуются правом на получение гражданства.

Основной источник получения гражданства помимо рождения, как мы сказали, - это натурализация. Натурализация предполагает в названных странах прохождение для искателя довольно жестких процедур. Общее правило - срок домицилия. В Латвии и Эстонии он составляет пять лет беспрерывного проживания (раздел 12 латвийского закона и $\S 6$ эстонского), в Литве срок - 10 лет (п. 2 ст. 12). Лицо, ходатайствующее о получении гражданства, должно достичь не менее 15 лет от роду. Оно должно сдать экзамен на знание государственного языка, знание конституции страны пребывания, иметь законный источник дохода, принести присягу верности государству. Только литовский закон этого не требует. Эстонский закон требует от соискателя еще проявления лояльности государству. Что это такое, думается, объяснить невозможно, но практика говорит нам, что помещение в сети Интернет материалов, критикующих политику властей, уже является достаточным основанием для отказа в получении гражданства в Эстонии ${ }^{7}$.

Законодательство весьма подробно регулирует прохождение соискателем экзамена на знание государственного языка. Данное положение кажется вполне оправданным, тем более что аналогичное требование российского закона (п. «д» ст. 13) представляет собой весьма нечеткую норму. Согласно, например, латвийскому закону «бегло говорить по-латышски» означает: полностью понимать информацию социальной и официальной направленности; свободно рассказывать, поддерживать разговор и отвечать на вопросы, касающиеся тем социальной направленности; бегло читать и понимать инструкции, указания и другие тексты социального характера; написать сочинение по теме социального свойства по предложению комиссии (в Эстонии это curriculum vitae) (раздел 20 латвийского закона). Лица, получившие среднее образование на государственном языке, освобождаются от сдачи подобных экзаменов, не сдают экзамены и лица старше 65 лет - это общее правило для прибалтийских стран.

7 Обстоятельства дела см.: Полещук В. Неграждане в Эстонии. М., 2005. С. 26. 
Тем не менее родимые пятна реституционизма дают о себе знать в этих законах весьма явственно. Наглядный пример - раздел 11 латвийского закона. Это большое положение, но в интересах дела постараемся процитировать его как можно полнее. Гражданство Латвии не предоставляется ни при каких условиях, если лицо неконституционными методами действовало против независимости Латвии, его властей. Ограничение этой нормы заключено в том, что требуется все же решение суда, определяющее, что данное лицо виновно в подобных деяниях. Гражданство не предоставляется, если лицо после 4 мая 1990 г. пропагандировало идеи шовинизма, фашизма, национал-социализма и коммунизма. Ограничение этого положение то же, что и предыдущее - решение суда.

Но вот для следующих категорий лиц такого решения не требуется. Им гражданство не предоставляется по определению. Это лица, которые после 17 июня 1940 г. (sic!) выбрали Латвию в качестве постоянного места жительства после демобилизации из рядов Вооруженных Сил СССР (России) или же Внутренних Войск СССР (России). Лица, являвшиеся работниками, информаторами, агентами и охранниками КГБ СССР (Латвийской ССР) или службы безопасности, разведки и других специальных подразделений любого иностранного государства. Сюда же относятся лица, которые после 13 января 1991 г. работали против Республики Латвии в КПСС, Компартии Латвии, Интернациональном фронте трудящихся Латвийской ССР, Объединенном совете трудовых коллективов, Организации ветеранов войны и труда, Вселатвийском комитете спасения или его региональных органах или же в Союзе коммунистов Латвии. Вот такая маленькая месть победителей!

Важно при этом отметить, например, такую особенность эстонского законодательства. В 1991 г. здесь был отменен закон «О невозвращении в Эстонию пособников нацистов», автоматически эта категория лиц получила право на восстановление в эстонском гражданстве. И теперь вполне безбоязненно проводит марши ветеранов войск СС. Данный фактор был расценен наблюдателями как значительный, существенно повлиявший на степень фашизации эстонского общества. Нечто подобное можно говорить и о Латвии, где степень фашизации явно зашкаливает. Вполне правомерно сделать на этом основании вывод, что политика в области гражданства в прибалтийских странах имеет цели, далекие от создания мира и спокойствия в обществе. 
Относительно недавние новеллы латвийского и эстонского законодательства касаются возможности получения гражданства названных государств несовершеннолетними или же в любом порядке лицами, рожденными после получения этими государствами независимости. Общее требование здесь - наличие домицилия, знание государственного языка, отсутствие судимостей и ряд других условий.

Важно подчеркнуть, что законами предусмотрена возможность судебного обжалования решения органа администрации, ответственного за предоставление гражданства. Тем не менее практика эта очень скудная. Вместо этого мы имеем ряд дел, проигранных, в частности, Латвией в Европейском суде по правам человека, в которых речь шла именно о гражданстве.

Режим получения гражданства в названных странах, как видим, является весьма жестким и имеет четко верифицируемую цель: как можно сильнее затруднить для этнически не титульного населения получение гражданства. Именно этой политикой объясняется наличие многочисленной группы так называемых неграждан в Латвии и Эстонии. Это воистину исключительно прибалтийское изобретение.

$$
* * *
$$

Прибалтийские страны в результате использования доктрины реституционизма в своей практике пришли к явно неоднозначному результату. Этот результат является своего рода изобретением нового, нигде более не встречающегося понятия «неграждане». Как отмечала Х.-М. Биркенбах: «Их статус уникален в европейском контексте и привел к появлению ряда нелепых ситуаций. Так, до 1995 года, в ходе четырех лет после восстановления независимости, власти республик все еще выдавали этим негражданам внутренние паспорта, как будто они все еще оставались гражданами государства, переставшего существовать в 1991 году. С 1996 года их документы советского времени стали заменяться «паспортами неграждан» или «паспортами иностранцев» ${ }^{8}$.

Обычно Литву рассматривают отдельно в этом русле национальной политики по сравнению с соседями по региону. Во многом это объясняется более легким отношением к этническим группам нелитовцев

8 Биркенбах Х.-М Расследование фактов как средство превентивной дипломатии: Взгляд международных организаций на конфликт по вопросу гражданства в Эстонии и Латвии. М.: ИЭА РАН, 1998. С. 29. 
после восстановления государственности. Но это не более чем расхожее мнение. Общий настрой политики литовских властей мало чем уступает этнической нетерпимости латышей или эстонцев ${ }^{9}$. Традиционное объяснение этому видят в соотношении этнических групп населения. В Литве национальных меньшинств относительно меньше, чем в Латвии и Эстонии. Это соотношение видно из следующей таблицы, по данным Всесоюзной переписи населения в 1989 г.:

\begin{tabular}{|l|l|l|}
\hline \multicolumn{1}{|c|}{ Эстония } & \multicolumn{1}{|c|}{ Латвия } & \multicolumn{1}{|c|}{ Литва } \\
\hline Эстонцев $61,52 \%$ & Латышей $51,77 \%$ & Литовцев $79,6 \%$ \\
\hline Русских $30,33 \%$ & Русских $34,17 \%$ & Русских $12 \%$ \\
\hline Украинцев $3,8 \%$ & Украинцев $3,44 \%$ & Поляков $8 \%$ \\
\hline Белорусов $1,77 \%$ & Белорусов $4,46 \%$ & \\
\hline
\end{tabular}

Формально угрозу государственности Литве скорее могут составить поляки - хотя бы возобновлением притязаний на район Вильно, где они до сих пор составляют большинство населения. Фактически национальная политика литовских властей не отличается от резко выраженной этнократической модели соседних режимов. Этнические русские практически лишены возможности участвовать в политической, экономической и культурной жизни Литвы. Даже зная литовский язык, русские часто не могут реализовать свой талант, профессиональные навыки, опыт и все более ощущают свою ненужность для республики. К такому выводу приходит Л.В. Остапенко, автор специального исследования на интересующую нас тему ${ }^{10}$.

Итак, кто же это такие - неграждане? «Негражданин, - гласит латвийский закон о гражданстве, - это лицо, которое согласно закону «О статусе бывших граждан СССР» не получило гражданство Латвии или любого другого государства и которое имеет право на получение паспорта негражданина, выдаваемого Республикой Латвией». В Эстонии отсутствует подобное легальное определение, поскольку закон об иностранцах (Välismaalaste seadus) 1993 г. не делает различия между собственно иностранцем или апатридом. Здесь в ходу сугубо этнический термин «эстонство» и «неэстонство».

9 Фактически восстанавливая прежний правопорядок, нормы прежнего законодательства о гражданстве, литовцы исповедали и исповедуют пресловутый реституционный подход: Ziemele I. The role of state continuity and human rights... P. 261.

10 Остапенко Л.В. Русские в Литве: сфера труда и проблема адаптации // Вынужденные мигранты: интеграция и возвращение. М., 1997. С. 239-240. См. также: Курьянов В.Н. Выход Литвы из СССР (внутренние и внешние политические факторы). Автореф. дис. „.. к.п.н. М., 1995. С. 20. 
Смысл этой дихотомии довольно призрачен. Эстонство (eestlus) это термин собирательный по своему значению, включающий этнические группы, принадлежащие по языку, крови (т.е. происхождению), культуре и т.п. к Эстонии. В понятие эстонства, например, включают всю диаспору эстонцев за рубежом, им гарантировано автоматическое получение гражданства в случае подачи простого заявления об этом. К этому понятию могут быть отнесены и народы финно-угорской языковой группы, например народность сету (setumaa), компактно проживающая в Печерском районе Псковской области. Более точного определения объема термина от его апологетов вы не добьетесь ${ }^{11}$. Да это и неважно, его предназначение - идеологическое обслуживание территориальных претензий к России и залог, обеспечивающий требования о компенсации ущерба за полувековую «оккупацию». В отношении последнего все прибалтийские государства уже приняли специальные законы о том, что Россия им должна. Логика этих законов, конечно, сугубо балтийская.

В отношении же такой довольно скользкой темы, как происхождение того или иного народа, можно заметить, что в Эстонии в последнее время добились явных «успехов». Здесь ведутся весьма активные изыскания, в том числе и в области популяционной генетики, с целью выявления ареала обитания племен, которых можно было бы представить предками эстонцев. Курьезность этих исследований заключена в том, что авторы этих работ взяли себе временную шкалу от окончания последнего ледникового периода, приблизительно 15000 лет назад, а выводы делают применительно к нашему времени ${ }^{12}$.

Продолжая терминологический анализ, следует обратить внимание еще на один термин, часто встречающийся на страницах прессы и в научных работах. Речь идет о пресловутых «русскоязычных». Возник он еще в годы перестройки в среде советской интеллигенции,

11 См. убедительный разбор составляющих этого термина: Рейнц Х., Родницкая 3. Феномен двойного стандарта и некоторые аспекты деятельности международных организаций в Эстонии. СПб., 2001. С. 31.

12 См. доступный русскому читателю обзор подобных исследований: Самоопределение и независимость Эстонии. Таллин, 2001. Стоит также обратить внимание на опус Э. Маттисена: Mattisen E. Searching for a dignified compromise. The Estonian-Russian border 1000 years. Tallin, 1996. Р. 11 и сл. Так, на с. 16 этого «труда» можно найти карту распространения очагов эстонской культуры в Бронзовом веке. Контуры этой карты странным образом совпадают с границами Эстонии по Юрьевскому договору. Маттисену осталось только одно - показать ареал обитания мамонтов на территории Эстонии, и тезис «Эстония - родина слонов» можно принять как неопровержимый. 
оторванной от своих национальных корней. Им воспользовались прибалтийские публицисты с целью более четкого противопоставления титульной нации мигрантам ${ }^{13}$. Вместе с тем глупость и бессмысленность этого термина очевидна. Это своего рода плеоназм вроде «мокрая вода». Бессмыслица станет еще более очевидной, если вспомнить, что значительное количество коренных жителей прибалтийских стран может быть отнесено к русскоязычным. Все они учили русский язык в школе, многие не забыли его ${ }^{14}$. Соответственно, применение этого термина к категории неграждан представляется неправильным, унижающим человеческое достоинство оскорблением.

Вполне резонен вопрос: каким образом сформировалась данная категория населения стран Прибалтики? Каков был правовой механизм его формирования? Ответ прост. Основание этого механизма лежит в доктрине реституционизма: «...поскольку международная личность прибалтийских государств не исчезла, то в силу этого они рассматриваются как продолжающие свое существование, по крайней мере de iure, как государства в международном праве. Вполне допустимо поэтому то, что вопросы гражданства и права человека в прибалтийских государствах не могут быть решены вне дискуссии о международно-правовом статусе этих государств» ${ }^{15}$. Логика очевидна: раз прибалты восстановили свою государственность, то вполне резонным кажется вопрос, насколько они должны распространять этот подход и на элементы государства. Вопрос, которым задается прибалтийский публицист от международного права, как говорится, из области риторических. Он сродни пресловутой балтийской логике, которая создает силлогизмы, основанные на постулатах тавтологического свойства idem per idem. Сами себе объявили континуитет, поэтому идентичность существует. Поэтому естественен ответ на этот риторический вопрос: континуитет государства совпадает с континуитетом гражданства. Следовательно, гражданство предоставляется не всем проживавшим на момент восстановления государственности, а только лицам, происхождение которых было идентично гражданству прежних государств.

13 Оправдание было проще пареной репы: «..надо иметь в виду и то, что в глазах коренной национальности и демографическая, и жилищная, и обострившаяся экологическая проблемы зачастую приобретают национальную тональность», - писал один такой публицист. Национальные отношения: проблемы и суждения. Рига, 1989. С. 60.

14 Как верно указывает И.А. Сухов: Сухов И.А. Русские в современной Эстонии. 1991-2000 гг. Автореф. дис. ... к.и.н. М., 2003. С. 4.

15 Ziemele I. Op. cit. P. 249-250. 
«Государства Латвии и Эстонии, - замечает в этой связи Х.-М. Биркенбах, - рассматриваются как единственные легитимные действующие лица. Они претендуют на признание их в качестве единственных, во власти которых определить, кому быть гражданами страны, а кому нет. Подспудно ожидается, что неграждане признают свой особый статус и, не жалуясь, смирятся с законодательством, регулирующим их жизнь» ${ }^{16}$. От себя можем добавить, что столь широкое понимание прав человека не вяжется с положениями международного права, о чем мы имели возможность говорить выше. Важно здесь другое - наглое попрание не то что права, а здравого смысла.

Налицо совершенно абсурдная ситуация. Органы государственной власти, принимавшие решение о реституционном восстановлении прежней государственности, были сформированы на основании законов другого государства и на основе волеизъявления другого населения, опять же если следовать балтийской логике. В результате получается парадоксальная вещь. Депутаты, избранные населением другого государства, принимают решение о непризнании значительной части этого населения своим; устанавливается при этом, что отсутствует правовая связь между этой группой населения и восстановленным государством. Утверждается, что существует обратная сила решения, принятого по лишению прав населения другого государства по отношению к правопорядку, прекратившему свое существование полвека назад ${ }^{17}$. Более того, провозглашенное восстановление государственности осуществляется теми людьми, мандат которых получен опять-таки в результате выборов от населения, правовой статус которого впоследствии признан недействительным. «Если следовать логике Верховного Совета [еще Латвийской ССР. - В.Ч.] 1990 года, - замечает В. Гущин, - то выборы в Верховный Совет 1990 года являются менее законными, чем выборы в Сейм в июне 1940 года. Объяснение этому выводу простое: в выборах в народный Сейм солдаты и командиры Красной Армии не участвовали, в то время как в выборах в Верховный Совет участвовали все жители Латвии, включая и солдат и командиров Советской Армии, являвшейся по логике Верховного Совета армией страны-оккупанта, что позволяет признать результаты этих выборов недействительными» ${ }^{18}$.

16 Биркенбах Х.-М. Указ. соч. С. 76.

17 Ziemele I. Op. cit. P. 256.

18 Гущин В. Этнократия: латвийский вариант. Рига, 2004. С. 38. 
Юриспруденция, правовая наука, которую изучают в цивилизованных странах мира, не знает ничего подобного. Оказывается возможно создание юридического факта средствами, post factum признанными неправовыми, с приданием этому решению обратной силы. В действительности перед нами классическая картина захвата власти, государственного переворота. Вас избрали на пост, а затем вы лишаете прав тех, кто вас избрал. Юридически это захват власти.

При этом особый цинизм политиканов, осуществляющих захват власти, проявляется в двух вещах. Первое: общеизвестно, что большинство русского населения стран Прибалтики на выборах 19891990 гг. голосовало фактически за независимость этих стран, против союзного центра ${ }^{19}$. Русские - будущие неграждане - оказались вполне лояльными идее независимости, и вполне очевидно было от них ожидать проявления этой лояльности впредь. Косвенно это подтверждается тем, что в жутких условиях национального угнетения в первые годы реституционной независимости они так и не прибегли к радикальным средствам борьбы, как, например, русские в Приднестровье.

Второе, скорее, характеризует моральный облик элиты современных прибалтийских стран, который остается вполне советским по духу. Нам не известно ни одного случая отказа от регалий, званий и т.п. благ, полученных от «проклятого оккупационного режима» деятелями культуры, искусства и гуманитарных наук, из среды которых вышло 90 \% руководителей народных фронтов, а потом уже и правительственных кабинетов и парламентов.

$$
* * *
$$

В результате сложения вышеуказанных факторов появляется особый тезис, общий для прибалтийских режимов: «Русскоязычные не являются апатридами, поскольку имеют право на гражданство России как страны - продолжателя СССР». Под этим лозунгом в Эстонии

19 Это общепризнанный факт: «После попыток вооруженного восстановления советской власти в Литве, Латвии и Эстонии популярность идей независимости среди русскоязычного населения беспрецедентно возросла. Это было зафиксировано результатами республиканских референдумов о независимости, проведенных в феврале - марте 1991 г. непосредственно перед всесоюзным референдумом 17 марта 1991 г.». Эстония: контуры этнополитической независимости 1988-1993. Т. 1. М., 1994. С. 14; Сухов И.А. Русские в современной Эстонии. С. 5; Зепа Б., Устинова М.Я. Интеграция русских в Латвии // Вынужденные мигранты: интеграция и возвращение. М.,1997. С. 225 и др. 
и отчасти в Латвии постарались сделать все от них зависящее, чтобы дезавуировать известный договор от 12 января 1991 г., подписанный тогдашним лидером РСФСР Ельциным и руководством боровшихся за самоопределение Латвии и Эстонии. Договор - это отдельная статья, а вот сам тезис примечателен своей юридической безграмотностью.

Как известно, между понятиями «иметь право» и «пользоваться этим правом» - большая разница. Наличие права не является основанием для отказа в получении другого права. Налицо своеобразный рудимент советской ментальности: «Не больше одного килограммов апельсинов в одни руки!» Как остроумно замечает автор предисловия к специальному докладу, посвященному положению неграждан в Эстонии: «Все евреи, например, имеют возможность получения гражданства государства Израиль, но это вовсе не основание отказывать им в гражданстве страны пребывания, в том числе и в Эстонии. Кроме того, такое искусственное навязывание постоянным жителям Эстонии гражданства иного государства никак не согласуется с целями и принципами демократической политики» ${ }^{20}$. Основание подобной позиции лежит в нежелании решать проблему в правовом ключе, а также надежда на своеобразный исторический реванш, опасность которому может составить «пятая колонна» - большая этническая община русских.

Свою лепту в этот процесс внесла сама Россия, активно вмешивавшаяся в иммиграционную политику прибалтийских стран по причине проблем собственной внутренней ситуации ${ }^{21}$. Позиция России, ельцинской России, во многом оказалась политиканствующей. Международный эксперт Х.-М. Биркенбах в этой связи отмечала: «Даже, если ситуацию можно было бы рассматривать как угрожающую национальной безопасности, как считают Латвия и Эстония, и если Россия и ее «аванпосты» действительно представляли бы угрозу для обеих стран, могли бы одни лишь призывы к России, которая воспринимается как главный

20 Полещук В. Неграждане в Эстонии. М., 2005. С. 6.

21 «Примечательно, что Россия, - пишет И.А. Сухов, - в течение почти всех 90-х годов в основном на уровне риторики отстаивала интересы российских граждан и граждан бывшего СССР в Эстонии, используя эту карту в интересах построения своих собственны контактов с Западом. В результате русские в Эстонии перестали почти полностью себя ассоциировать с Россией - у них начала активно формироваться собственная идентичность балтийских, эстонских или европейских русских». Сухов И.А. Русские в Эстонии. С. 18. Факт, отмеченный Суховым, абсолютно достоверен (см. обобщающее исследование: Симонян Р.Х. Новый балтийский субэтнос «еврорусские» // Социология власти. 2004. № 2). 
враг, стать действенными? Кроме того, Эстония и Латвия, обращаясь только к действующим лицам из-за рубежа с призывами предпринять какие-либо действия, лишают себя возможности развивать независимую стратегию для интеграции неграждан российского происхождения, живущих в их обществах. Желание преподать урок «этим» русским, а также принуждение неграждан использовать государственный язык и проходить процедуры натурализации никоим образом не станут противодействием русской угрозе. Напротив, независимость Латвии и Эстонии от окружающих их стран, и в первую очередь от «доброй воли» России, будет увеличиваться, пока они не сознают необходимости превратить российскую угрозу в добрососедские отношения» ${ }^{22}$. Эту точку зрения нельзя не признать обоснованной и здравой.

В сухом остатке мы видим группу лиц, чей правовой статус до сих пор не соответствует принятым стандартам цивилизованного мира. Известный норвежский юрист-международник, специалист в области прав человека Асбьерн Айде совершенно верно заметил: «Трудно признать факт, что к лишенной гражданских прав части населения следует относиться как к обычным иностранцам. Они приехали сюда, не предполагая, что будут рассматриваться в качестве иностранцев; как граждане Советского Союза, они воспользовались правом на свободу передвижения в границах государства, гражданами которого они были; они не были рабочими-мигрантами, приехавшими в Эстонии и Латвию как в государства с самодостаточной экономикой» ${ }^{23}$.

Теперь же посмотрим еще на одну особенность появления группы неграждан. Эта особенность - прямое игнорирование Эстонией и Латвией двусторонних договоренностей с Россией. Известно, с какими трудностями проходил «диалог» цивилизованных прибалтов с диким и некультурным союзным центром на закате перестройки. В самый, казалось бы, пик напряженности руководство РСФСР пришло на помощь изнемогавшим прибалтам. Тогда все это казалось не более чем эпизодом в противостоянии между Ельциным и Горбачевым в лидерстве, в борьбе за перестройку. Договор от 12 января 1991 г. между РСФСР и Эстонией (аналогичное соглашение было заключено и с Латвией) устанавливал основы межгосударственных отношений между Россией и Эстонией.

22 Биркенбах Х.-М. Указ. соч. С. 77.

${ }^{23}$ Цит. по: Биркенбах Х.-М. Указ. соч. С. 120. Доклад этого эксперта помещен в качестве приложения к названному труду. 
Так, ст. 3 названного договора постановляла, что стороны берут на себя обязанность обеспечить лицам, которые в момент подписания живут на территории Эстонии и РСФСР и являются гражданами CCСР, право сохранить или получить гражданство Эстонии или России «по их свободному волеизъявлению». Далее в этой же статье говорилось: «Связанные с гражданством вопросы, представляющие для сторон интерес, согласуются особо в двухстороннем соглашении, которое основывается на международных нормах». Следующая статья договора, ст. 4, предоставляла всем лицам вне зависимости от национальности право выбора гражданства, то есть устанавливала право оптации.

Данная ситуация представляется во многом парадоксальной не потому, что оба подписанта находились в тот момент в положении непризнанных субъектов международного права, аналогичном тому, в котором были РСФСР и Эстония на момент подписания Юрьевского договора, а потому, что впоследствии Латвия и Эстония стали ссылаться на договоренность, зафиксированную в тексте договора о дальнейшем регулировании вопроса как на главное препятствие возможности договориться с Россией вообще 24 . Было совершено еще одно открытие в духе балтийской логики. Оказывается, нормы внутреннего права прибалтийских государств имеют приоритет над нормами международного, хотя Венская конвенция о праве международных договоров 1969 г. (ст. 27) запрещает стороне ссылаться на положение внутреннего права как на основание невыполнения обязательств по международному договору. Кроме того, сомнительно, будто положения «особых соглашений», развивающих положения основного договора, могли бы противоречить его общей норме, а такова позиция Латвии и Эстонии, ссылающихся на положения внутреннего права, принятые после заключения договора, после обретения независимости. Если бы у этих господ была бы хоть капля чувства реальности, то сослались бы, в конце концов, на clausula rebus sic stantibus. Но с квалифицированными юристами у прибалтов большая проблема. Основа их логики: сами напринимали, сами же и считаем то, что́ приняли, верхом юридического совершенства. Одним словом, fiat iusticia et pereat mundum.

\footnotetext{
24 Международный эксперт свидетельствует: «Все эксперты сошлись также во мнении и практически признали тот факт, что ни Эстония, ни Латвия не предоставили гражданство всем тем, кто к моменту восстановления независимости проживал на территории, как было обещано во время борьбы за независимость и прозвучало в обсуждении с Россией в 1991 году». Биркенбах Х.-М. Указ. соч. С. 51.
} 
В результате, несмотря на ряд косметических мер, в Латвии и Эстонии значительное число этнических русских продолжают оставаться негражданами. Их право на гражданство, таким образом, отрицается властями названных стран, что противоречит общим принципам и нормам международного права в этой сфере.

\section{Nationality's Questions in the Practice of the Baltic States \\ (Summary)}

\section{Vladimir B. Chernoletsky*}

Legal status of an individual in the modern state is the key element of the state system. The question is, to what extent having a right to nationality results in an actual possibility of enjoying this right. This particular issue has become extremely pressing in the light of the practice employed by the Baltic "powers" with respect to the legislation on nationality.

Modern international law treats the actual possibility of obtaining such right or exercising it as one of the key, fundamental personal rights, which, given the declared primacy of the international law over the national law, becomes a sort of conditio sine qua non to the state system of a particular state being civilized. Where are the Baltic states with this, as a matter of practice?

The selective approach adopted by the Baltic regimes to applying international law rules is still being supported by the Western community.

The regulation with respect to obtaining nationality is quite tight and has a clearly verifiable purpose - to hinder obtaining nationality for the part of the population not belonging to the ethnic majority as much as possible. This particular policy explains the existence of a vast group of so called non-citizens in Latvia and Estonia. This is a unique Baltic invention.

Notwithstanding a number of cosmetic measures, a significant number of the ethnic Russians in Latvia and Estonia still remain non-citizens. Thus, their right to nationality is denied by the authorities of the said countries, which contravenes the applicable general principles and rules of international law.

\footnotetext{
* Vladimir B. Chernoletsky - deputy head of the office of scientific planning of the Scientific Policy Department, MGIMO-University MFA Russia.
} 